\title{
Indonesian Journal of Guidance and Counseling:
} Theory and Application

\author{
http://journal.unnes.ac.id/sju/index.php/jbk
}

\section{Konseling Traumatik Dengan CBT: Pendekatan dalam Mereduksi Trauma Masyarakat Pasca Bencana Tsunami di Selat Sunda}

\section{Elfi Rimayati}

Jurusan Bimbingan dan Konseling, Universitas Ivet Semarang, Semarang, Indonesia

\section{Info Artikel}

Sejarah Artikel:

Diterima 14 Mei 2019

Disetujui 21 Mei 2019

Dipublikasikan 30 Juni 2019

Keywords:

Academic Procrastina-

tion; Social Support;

Time Management

DOI :

https://doi.org/10.15294/ijgc. v8i1.28273

\begin{abstract}
Abstrak
Indonesia termasuk salah satu negara yang potensial bencana alam termasuk tsunami. Secara geografis indonesia berada di wilayah patahan gempa, dan banyak gunung berapi yang kondisinya masih aktif. secara historis sejak tahun 1968- 2006 telah terjadi 7 kali gempa yang diikuti tsunami. Di penghujung tahun 2018, bencana tsunami terjadi Selat Sunda. Ada dua daerah yakni Banten dan Lampung yang menjadi korban tsunami. Dampak psikologis yang terjadi akibat tsunami adalah trauma. Permasalahan trauma di masyarakat seringkali menjadi disfungsi psikologis yang sangat mengganggu. Oleh karena itu dibutuhkan upaya bantuan yang fokus pada penyelesaian masalah trauma. Konseling traumatik menjadi salah satu alternatif dalam membantu menyelesaikan permasalahan tersebut. Konseling traumatik fokus pada mengembalikan kondisi trauma masyarakat ke kondisi psikologis yang sehat. Adapun Cognitive Behavioral Therapy (CBT) dipilih karena CBT merupakan teknik konseling yang menggabungkan terapi kognitif dan terapi prilaku. Terapi kognitif penting diberikan kepada korban, karena orang yang menjadi korban seringkali memiliki pemikiran yang tidak rasional, kehilangan harapan, serta sulit terhubung dengan dunia nyata. Oleh karena itu mereka mengalami gangguan perilaku seperti murung, sulit berkomunikasi secara sehat, prilaku pasif tidak mau bangkit dari keterpurukan dan sebagainya. Terapi behavioral menjadi bagian penting yang tak terpisahkan. Melalui konseling traumatic dengan CBT dapat mereduksi trauma masyarakat akibat tsunami di Selat Sunda.
\end{abstract}

\section{Abstract}

Indonesia is one of the countries with potential natural disasters including tsunamis. Geographically Indonesia is in an earthquake fault area, and many volcanoes are in active condition. Historically since 1968- 2006 there have been 7 earthquakes followed by tsunamis. At the end of 2018, the tsunami disaster occurred in the Sunda Strait. There are two regions, Banten and Lampung, which were victims of the tsunami. The psychological impact of the tsunami is trauma. The problem of trauma in the community is often a very disturbing psychological dysfunction. Therefore, a real effort is needed to focus on solving trauma problems. Traumatic counseling is one alternative in helping to solve these problems. Traumatic counseling focuses on returning the community's trauma to a healthy psychological condition. The CBT was chosen because CBT is a counseling technique that combines cognitive therapy and behavioral therapy. Cognitive therapy is important given to victims, because people who are victims often have irrational thoughts, lose hope, and are difficult to connect with the real world.Therefore they suffer from behavioral disorders such as moodiness, difficulty communicating in a healthy manner, passive behavior, and do not want to rise from adversity. Behavioral therapy is an important part that is inseparable. Through traumatic counseling with CBT can reduce community trauma due to the tsunami in the Sunda Strait.

How to cite: Kristy, Dije Zaraska. (2019). Manajemen Waktu, Dukungan Sosial, dan Prokrastinasi Akademik Siswa Kelas XI SMA . Indonesian Journal of Guidance and Counseling: Theory And Application, 8(1), 55-61. https://doi.org/10.15294/ijgc. v8i1.28273

(C) 2019 Universitas Negeri Semarang p-ISSN 2252-6374

Alamat korespondensi: e-ISSN 2597-6133 


\section{PENDAHULUAN}

Bencana alam merupakan bagian yang tidak terpisahkan dari kehidupan manusia, sejarah telah mencatat berbagai macam bencana alam di seluruh penjuru dunia, tak terkecuali negara Indonesia. Salah satu bencana alam yang sering terjadi di Indonesia adalah tsunami. Indonesia termasuk salah satu negara yang rawan akan bencana disebabkan posisi geografisnya. Beberapa wilayah Indonesia terletak di daerah patahan gempa. Banyak juga wilayah yang memiliki gunung berapi yang masih aktif. Pratama (2008) dalam tulisannya menjelaskan tentang bencana tsunami yang melanda Indonesia sejak tahun 1968. Selama rentang waktu 38 tahun Indonesia mengalami tujuh kali bencana gempa yang diikuti tsunami. Pada 10 Agustus 1968 terjadi gempa bermagnitudo 7,3 mengguncang Sulawesi Tengah, dan diikuti tsunami di daerah Donggala tiga hari kemudian. Pada 19 Agustus 1977 terjadi gempa bumi yang disertai gelombang tsunami terjadi di lepas pantai Sumba NTT. Pada 12 Desember 1992 gempa diikuti tsunami terjadi di Flores NTT. Kemudian tsunami juga menyapu wilayah Banyuwangi Jawa Timur, pada 3 Juni 1994. Wilayah Indonesia yang terkena bencana tsunami berikutnya adalah kabupaten Banggai kepulauan Sulawesi Tengah, terjadi pada 4 Mei 2000. Empat tahun berikutnya tepatnya pada 26 desember 2004 gempa bumi berkekuatan 9,3 SR mengguncang wilayah Aceh diikuti tsunami yang sangat dahsyat. Ketika duka Indonesia belum usai, pada 17 Juli 2006 tsunami kembali memporak-porandakan Indonesia, kali ini terjadi di wilayah Pangandaran Jawa Barat.

Setelah 12 tahun berselang Indonesia kembali diguncang bencana tsunami di penghujung tahun 2018, tepatnya pada hari Sabtu tanggal 22 Desember 2018. Tsunami terjadi di Selat Sunda. Badan Nasional penanggulangan Bencana (BNPB) menyampaikan korban meninggal akibat tsunami di selat Sunda terus bertambah. Data terbaru pada Selasa 25 desember 2018 pukul 13.00 WIB menyatakan korban meningal berjumlah 429 orang. Tsunami tersebut berdampak pada lima kabupaten yaitu Pandeglang, dan Serang di propinsi Banten, serta kabupaten Lampng selatan, Pesawaran, dan Tanggamus, propinsi Lampung. Dari lima kabubaten tersebut dampak terparah dilami kabupaten Pandeglang tercatat 290 orang meninggal, 1143 orang luka-luka, 77 hilang dan 14.395 mengungsi. (www.liputan6.com).

Kondisi ini sangat berdampak pada sisi fisik maupun psikologis masyarakat. Kesedihan yang mendalam karena kehilangan anggota keluarga, sanak saudara, sahabat dan orangorang tercinta, kehilangan harta benda, tempat tinggal, barang-barang berharga, mata pencaharian bahkan mereka kehilangan harapan hidup. Akibat dari bencana tsunami ini banyak masyarakat yang mengalami ganggunan psikologis seperti tertekan, murung, depresi dan trauma. Nurrachman (2007) menyebutkan peristiwa bencana alam mengakibatkan keseimbangan kondisi psikologis seseorang terganggu. Ada tiga faktor yang mengakibatkan hal tersebut terjadi. Pertama, peristiwa bencana alam itu sendiri yang "menakutkan dan mengancam keselamatan jiwa". Kedua, wafatnya orang-orang yang disayangi dan hilangnya harta benda yang dimiliki. Ketiga, kehilangan mata pencaharian dan kesulitan memenuhi kebutuhan dasar hidup.

Mereka membutuhkan bantuan, baik berupa bantuan pemulihan fisik maupun psikologis. Namun dalam kenyataan bantuan yang diberikan baik oleh pemerintah maupun masyarakat lebih banyak pada pemulihan fisik, seperti mendatangkan alat-alat berat untuk proses evakuasi, proses pembersihan, pengiriman tenaga medis dan pemberian obat-obatan, sumbangan pangan (sembako), pakaian, bantuan perahu untuk pemulihan ekonomi nelayan, bantuan benih ikan untuk dibudidayakan, modal usaha dan pelatihan perintisan usaha (http://www.tribunnews.com). Kementerian sosial atas nama pemerintah juga lebih banyak memberikan bantuan yang bersifat pemulihan fisik. Menteri Sosial Agus Gumiwang Kartasasmita dalam menanggapi masalah korban bencana tsunami di selat Sunda menjelaskan bahwa program Perlindungan Sosial Korban Bencana Alam meliputi tiga tahap, yaitu pra bencana, saat bencana dan pasca bencana. Pada tahap pra bencana kementerian sosial melakukan pembangunan sistim kesiapsiagaan dan mitigasi bencana (penyiapan bufferstock logistik, sarana prasarana, TAGANA, Kampung siaga bencana, petugas. Saat bencana, pemerintah melakukan aktivasi sistim yang sudah disiapkan untuk penanggulangan bencana alam secara terpadu, yaitu klaster nasional yang dikoordinasikan oleh Badan Nasional Penanggulangan Bencana, Kemensos bertugas dalam klaster Perlindungan dan pengungsian dan klaster logistik. Pada tahap pasca bencana, Kemensosn melakukan pemulihan dan penguatan korban, yaitu memberikan bantuan pemulihan sosial (jaminan hidup, BBR, santua- 
nan dan isi hunian tetap, serta layanan dukungan psikossosial. Dukungan psikososial diberikan dalam bentuk menyanyi dan bercerita, pendirian posko lapangan futsal. (http://www. tribunnews.com).

Relawan yang memberikan trauma hiling, seperti yang dilakukan oleh CT ARSA Foundation Bersama Komunitas ARSA Banten melakukan trauma hiling untuk memulihkan trauma dan mengurangi beban penderitaan para korban. Hal yang dilakukan adalah mengajak masyarakat untuk senam pagi bersama, pemberian motivasi kepada anak-anak dengan menulis dan menggambar cita-cita, membagikan susu UHT dan makanan sehat serta penyuluhan tentang hidup sehat. (http://www. tribunnews.com).

Dari penjelasan diatas dapat diketahui bahwa pemberian konseling traumatik dengan Cognitive Behavioral Therapy (CBT) sebagai upaya pemulihan terhadap korban bencana tsunami di Selat Sunda belum dilakukan. Konseling traumatik merupakan upaya bantuan yang diberikan kepada konseli yang mengalami trauma, agar bisa keluar dari gangguan traumatisnya, dan dapat mengambil hikmah dari peristiwa yang dialaminya, sehingga ia bisa memiliki kesadaran penuh untuk bisa hidup secara wajar dan membangun masa depan yang lebih baik. Adapun pemilihan CBT (Cognitive Behavioral Therapy) lantaran masyarakat yang menderita traumatik seringkali mengalami gangguan psikologis yang berdampak pada gangguan kognitif dan perilakunya akibat kehilangan (orang-orang yang dicintai, harta benda, mata pencaharian). Menurut dr. Eka Viora, SpKJ, selaku Ketua Persatuan Dokter Spesialis Kedolteran Jiwa, orang yang mengalami kehilangan akan timbul rasa sedih berlebihan. Mereka akan mengalami kecemasan, kaget, shock, tidak percaya dan gelisah. Jika tidak cepat diatasi akan mengakibatkan gangguan jiwa ringan hingga sedang. Dalam kasus korban tsunami Selat Sunda yang kehilangan anggota keluarga, dibutuhkan dukungan psikososial dari psikiater, psikolog atau relawan untuk bisa bangkit dari kesedihan (http:// www.suara.com/health/2018). Teknik CBT yang merupakan gabungan dua terapi yaitu terapi kognitif dan terapi perilaku dipandang tepat dalam membantu memulihkan masalah traumatik. Hal ini didasarkan pada kondisi seseorang yang mengalami trauma seringkali mengalami gangguan kognitif/ berfikir dan gangguan perilaku. Yusuf (2013) Cognititive Behavior Therapy adalah terapi yang mem- berikan fokus pada cara bagaimana seseorang mengubah pemikiran atau keyakinan yang negatif (Beck,1995). Terapi ini bertujuan untuk membantu seseorang dalam memecahkan masalah-masalah terkait ketidak berfungsian emosional, perilaku dan kognisi secara sistematis, melalui terapi ini klien akan dapat berubah jika mereka berfikir secara berbeda, karenanya, terapis Cognitive Behavior Therapy lebih memfokuskan diri pada upaya mengajarkan ketrampilan self-counseling yang rasional.

\section{PEMBAHASAN}

\section{A. TRAUMA}

Trauma merupakan keadaan dimana seseorang mengalami gangguan baik fisik maupun psikologis akibat kejadian/pengalaman yang cukup mengerikan dan membuat mereka tidak berdaya. Trauma juga sering dikaitkan dengan kondisi seseorang yang terpuruk akibat pengalaman pahit yang menimpanya. Weaver, Flanelly dan Preston, 2003 dalam Nirwana (2012) trauma merupakan suatu kejadian fisik atau emosional yang cukup serius yang mengakibatkan kerusakan dan ketidakseimbangan secara substansial terhadap fisik dan psikologis seseorang dalam jangka waktu yang relatif lama. Sementara trauma psikis dalam psikologi diartikan sebagai anxiety/kecemasan hebat dan mendadak akibat kejadian di lingkungan individu yang melampaui batas kemampuannya untuk bertahan, mengatasi atau menghindar. Di samping itu trauma merupakan suatu kondisi emosional yang terus berlanjut setelah suatu kejadian trauma yang tidak menyenangkan, menyedihkan, menakutkan, mencemaskan dan menjengkelkan. Trauma psikis terjadi ketika seseorang dihadapkan pada peristiwa yang menekan yang menyebabkan rasa tidak berdaya dan dirasakan mengancam. Reaksi umum terhadap kejadian dan pengalaman yang traumatis adalah berusaha menghilangkannya dari kesadaran, namun bayangan kejadian itu tetap berada dalam memori. Konseling traumatik menjadi kebutuhan yang urgen untuk membantu para korban mengatasi beban psikologis yang diderita akibat bencana gempa dan tsunami. (Pusat Konseling Trauma: 2018).

Sejalan dengan dua definisi di atas, Nurrochman (2007) menyatakan bahwa dalam bidang psikologi, istilah trauma merupakan suatu pengalaman mental yang luar biasa menyakitkan karena melampaui batas kemampuan seseorang untuk menanggungnya. Trauma 
bersumber pada pengalaman traumatik. Secara umum, pengalaman traumatik memiliki ciri-ciri: terjadi diluar kendali orang yang mengalaminya, dapat mengancam kehidupan, berakibat ketakutan dan traumatik yang mendalam. Menurut Nurihsan dalam Muthmainnah (2013) seseorang yang terjebak dalam kondisi lingkungan yang rawan dan merugikan, seperti berbagai jenis bencana alam, terkena ledakan bom, terjadi banjir bandang, musibah kebakaran, mendapatkan tekanan dari teman bisa menyebabkan keadaan takut/ tertekan. Apabila keadaan ini berlangsung sering terjadi akan berdampak pada psikologis yang sakit yang disebut dengan istilah trauma.

Nurrochman (2007), juga menyatakan bahwa secara umum, ketika seseorang mengalami trauma, apapun peristiwa yang melatarbelakanginya (pemerkosaan, peganiayaan, atau bencana alam yang dahsyat) reaksi yang mencul dapat dikelompokkan menjadi 3 hal, yaitu: ingatan terganggu, berupaya menghindar, munculnya gangguan fisik. Ketiga jenis reaksi ini berdampak negatif terhadap aktifitas atau interaksi sosial seseorang sehari-hari atau dengan perkataan lain fungsi sosial mereka terganggu. Untuk itu harus segera dilakukan pemulihan agar mereka bisa kembali menjalani kehidupannya secara lebih baik. Beberapa proses pemulihan terhadap seseorang yang mengalami trauma, yaitu: tersedianya situasi yang aman dan nyaman, adanya dukungan sosial dan psikologis dari tokoh yang penting, adanya perasaan kebersamaan untuk saling menguatkan, serta adanya bantuan untuk proses pemulihan baik bantuan fisik maupun psikis.

\section{A. KONSELING CBT UNTUK MER- EDUKSI TRAUMA}

Konseling merupakan upaya bantuan yang diberikan kepada konseli (individu yang membutuhkan) dalam rangka menyelesaikan masalah yang dihadapi. Adapun konseling CBT adalah konseling yang menggunakan pendekatan CBT dalam menyelesaikan masalahnya. Masalah yang dialami oleh masyarakat korban bencana alam tsunami di Selat Sunda (Banten dan Lampung) adalah trauma. Sebagaimana disebutkan oleh Nurrochman (2007) ciri-ciri individu yang mengalami trauma adalah ingatannya terganggu, berupaya menghindar, dan munculnya gangguan fisik. Ketiga jenis reaksi ini berdampak negatif terhadap aktifitas atau interaksi sosial seseorang sehari-hari, dikarenakan adanya gangguan pada fungsi kognitif dan perilakunya.

Cognitive-Behavioral Therapy (Priscilla,2007) menggabungkan dua jenis psikoterapi yang sangat efektif, yaitu terapi kognitif dan terapi perilaku. Tingkah laku terapi, berdasarkan pada teori pembelajaran, membantu klien melemahkan koneksi antara pikiran dan situasi yang menyusahkan dan reaksi kebiasaan terhadap mereka. Terapi kognitif mengajarkan klien bagaimana pola berfikir mereka menjadi penyebab kesulitan mereka, dengan memberi mereka gambaran yang menyimpang dan membuat mereka merasa cemas, tertekan atau marah (Beck,1995). Ketika digabungkan dalam CBT, terapi prilaku dan terapi kognitif menyediakan alat yang kuat untuk mengurangi gejala dan membantu klien melanjutkan fungsi normal. Pendekatan kognitif telah ditemukan sebagai kerangka kerja yang cocok untuk terapi trauma karena pengalaman traumatis biasanya menghambat proses emosional yang bertentangan dengan skema kognitif yang sudah ada sebelumnya (Jaycox, Zoellner\& Foa,2002). Disonansi kognitif yang terjadi ketika pikiran, ingatan dan gambaran trauma tidak dapat didamaikan dengan struktur makna saat ini menyebabkan kesusahan. Sistim kognitif didorong oleh kecenderungan penyelesaian: kebutuhan psikologis" untuk mencocokkan informasi baru dengan model batin berdasarkan informasi yang lebih dulu, dan perbaikan kedua sampai mereka menyetujui" (Horowiz, 1986.p.92).

Adapun pelaksanaan/praktik konseling CBT dalam mereduksi masalah trauma masyarakat korban tsunami di Selat Sunda, dapat menggunakan kerangka konseling CBT sebagaimana yang ditawarkan Froggatt (2009:45). Ada enam tahapan yang harus dilakukan, yaitu: pertama, engange client (bekerjasama dengan klien/konseli), yaitu bekerjasama dalam menciptakan hubungan yang hangat, penuh empati dan sikap penghargaan, sehingga mereka merasa ditemani dan diterima. Hal ini didasarkan pada satu keadaan dimana korban bencana tsunami di Selat Sunda adalah individu yang sedang mengalami gangguan psikologis berupa traumatik yang dicirikan dengan emosi yang labil, memiliki tingkat kecemasan yang tinggi, menyalahkan diri sendiri, merasa kurang beruntung, dan tak berdaya. Mereka membutuhkan kehadiran orang-orang yang dapat membuat mereka nyaman secara psikologis, tulus memberikan perhatian dan penghargaan bahwa mereka bisa bangkit dan masih memiliki masa depan yang baik. Dalam 
kondisi penuh penerimaan dan penghargaan ini konselor akan mudah dalam memberikan intervensi mengubah pemikiran-pemikiran negatif mereka, dan mengorientasikannya pada pemikiran positif untuk bisa mengambil hikmah dari peristiwa traumatik yang dialaminya.

Kedua, Assess the problem, person and situation (asesmen terhadap permasalahan, orang dan situasi). Pada tahap ini konselor melakukan penilaian terhadap masalah traumatik yang dihadapi individu beserta situasi yang melingkupinya. Penilaian ini bertujuan untuk mengetahui sejauhmana gangguan traumatik yang dialami para korban bencana tsunami di Selat Sunda. Penilaian harus didasarkan pada kondisi gangguan traumatik tiap-tiap individu, mengingat setiap individu memiliki perbedaan tingkat terhadap respon ketika menghadapi bencana. Penilaian ini juga dimaksudkan untuk mendapatkan riwayat pribadi dan sosial para korban, menilai tingkat keparahan masalah traumatiknya, menilai setiap faktor kepribadian yang relevan dan menilai apakah ada gangguan sekunder yang menyertai serta bagaimana perasaan mereka terhadap hal ini. Menurut Rusmana (2012) asesmen dan diagnosis ini dimaksudkan untuk mendapatkan data yang benar tentang kondisi para korban sehingga tidak terjadi kesalahan dalam memberikan bantuan dalam pemulihan gangguan traumatiknya.

Ketiga, Prepare the klien for therapy (mempersiapkan konseli untuk melakukan terapi). Pada tahap ini konselor mempersiapkan konseli (individu yang mengalami gangguan traumatik) untuk melakukan terapi melalui konseling CBT. Konselor dan konseli menyepakati bersama tentang tujuan yang ingin dicapai dalam proses konseling. Dalam konseling CBT tujuan yang ingin dicapai adalah terjadinya perubahan kognitif/pemikiran dan perilaku yang maladaptif dan disfungsional dari konseli, sehingga mereka dapat kembali menjalani kehidupannya secara sehat (fisik dan psikhis) dan mandiri. Untuk mencapai tujuan ini konselor terus memberikan motivasi kepada konseli untuk berubah. Dasar-dasar Cognitive Behavioral Therapy (CBT) diperkenalkan, dan dijalaskan. Konselor memberikan penjelasan bagaimana pemikiran-pemikiran dan perilaku maladaptif akibat traumatik itu justru merugikan mereka, berdampak negatif bagi kehidupan mereka baik jangka pendek maupun jangka panjang, untuk itu harus dirubah. Konselor kemudian menjelaskan bagaimana cara merubah pemikiran dan prilaku maladaptif tersebut. Konselor dan konseli berdiskusi bersama tentang pendekatan dan langkah-langkah yang akan diambil dalam merubah pemikiran dan perilaku mereka. Hasilnya dijadikan kesepakatan bersama dan menjadi program terapi yang akan dilaksanakan bersama.

Keempat, Implement the treatment programe (mengimplementasikan program penanganan). Pada tahap ini konselor mulai mengimplementasikan program yang telah disepakati bersama yaitu melakukan langkahlangkah dalam proses konseling traumatik dengan CBT. Langkah pertama yaitu mengubah keyakinan konseli yang maladaptif (dikenal sebagai pencatatan fikiran atau analisis rasional). Individu yang mengalami trauma biasanya memiliki keyakinan yang maladaptif seperti merasa hancur, tidak bisa bangkit, tidak punya harapan masa depan dan merasa tidak dicintai (oleh manusia dan Tuhan). Konselor melakukan identifikasi terhadap pemikiranpemikiran mereka yang tidak rasional, mengumpulkan bukti bahwa pemikiran itu tidak rasional dan mengajak mereka untuk melawan pemikiran tersebut, kemudian mengajari mereka keterampilan untuk mengubah keyakinankeyakinannya yang keliru yang mengganggu emosi dan aktifitas mereka. Konselor memberikan intervensi melalui pengembangan CBT untuk mengurangi ketakutan, kecemasan, keputus asaan, dan ketidakberdayaan serta keyakinan-keyakinannya yang maladaptif. Kenselor juga memberikan intervensi modifikasi cara berperilaku. Mengajari mereka keterampilanketeranpilan cara mengubah perilaku. Pada intervensi tingkah laku, konseli diajak untuk melakukan pembelajaran, pengkondisian serta membuktikan pengalaman traumatisnya. Pada tahap ini konselor bisa memberikan strategi dan teknik tambahan yang sesuai misalnya pelatihan relaksasi dan pelatihan keterampilan interpersonal.

Kelima, Evaluative Progres (mengevaluasi kemajuan). Pada tahap ini konselor melakukan evaluasi terhadap tindakan yang telah dilakukan. Evaluasi ini bertujuan untuk mengetahui sejauhmana kemajuan yang telah dicapai konseli dalam hal perubahan kognitif dan perilakunya. Apakah keyakinankeyakinan yang maladaptif dan disfungsional akibat traumatiknya telah berubah menjadi keyakinan-keyakinan yang positif? Apakah tingkah lakunya juga telah berubah menjadi tingkah laku yang wajar sebagaimana tingkah laku individu yang sehat psikolologisnya? Jawaban atas dua pertanyaan ini menunjukkan 
perubahan yang telah dicapai konseli. Di sesi ini Rusmana (2012) menambahkan tahap yang disebut sebagai perubahan core believe. Pada tahapan ini konselor mengajak konseli untuk menyadari manfaat terapi melalui konseling CBT yang telah dilakukan. Setelah melakukan pendekatan dan intervensi kognitif dan intervensi tingkah laku, diharapkan struktur kognitif konseli dan perilakunya bisa kembali normal, yaitu ditandai dengan mereduksinya traumatik mereka. Pada akhirnya mereka bisa mengambil hikmah dari bencana tsunami yang dialami serta memiliki keyakinan bahwa trauma adalah sesuatu yang merugikan kehidupan mereka. Ansrori, (2015), menyatakan beberapa penelitian membuktikan efektivitas Terapi Kognitif Perilaku untuk mengatasi gangguan kecemasan seperti gangguan obsesif kompulsif (Abramowitz, Taylor, \& McKay, 2005; Whittal \& O'Neill, 2003), serangan kepanikan (McClanahan \& Antonuccio, 2002), gangguan cemas yang menyeluruh (Anderson, 2004). Juga terapi untuk mengatasi gangguan stress/tertekan pasca trauma (Sijbrandi, Olff, Reitsma, Carlier, Devries, \& Gersons, 2007).

Keenam, Prepare the client for termination (Mempersiapkan konseli untuk mengakhiri proses konseling). Pada tahap ini konselor menyampaikan tentang pentingnya konseli memiliki keterampilan dalam menghadapi dan menyelesaikan masalah secara mandiri. Sebelum sesi konseling berakhir, konselor memberikan penguatan terhadap hasil yang telah dicapai. Juga menyampaikan tentang adanya kemungkinan pengulangan masalah (gempa, tsunami, traumatik), sehingga konseli memahami cara menyelesaikan masalah secara mandiri jika pengulangan tersebut benar-benar terjadi. Keterampilan ini sering disebut sebagai self-help atau self-counseling.

\section{KESIMPULAN}

Bencana tsunami di Selat Sunda memberikan dampak psikologis bagi masyarakat di wilayah Banten dan Lampung serta sekitarnya. Traumatik akibat bencana tsunami yang mereka alami perlu mendapatkan penanganan yang serius. Bantuan berupa konseling untuk mereduksi traumatik mereka belum banyak dilakukan. Dalam perspektif bantuan pemulihan psikologis, konseling CBT (Cognitine Behavioral Therapy) menjadi alternatif solusi yang tepat dalam mereduksi masalah traumatik mereka. Pemberian layanan konseling CBT bagi korban bencana tsunami di Selat Sunda memerlukan enam tahapan: pertama, Engange client, layanan dimulai dengan menciptakan hubungan yang nyaman, penuh empati dan penghargaan serta hangat antara konselor dan konseli. Kedua; Assess the problem, person and situation. pada tahap ini konselor melakukan asesmen terhadap masalah, orang lain dan situasi untuk mengetahui latar belakang dan tingkat masalah konseli. Ketiga; Prepare the klien for therapy, konselor mempersiapkan konseli untuk terapi, memberikan motivasi untuk berubah serta menjelaskan prosesnya. Keempat, Implement the treatment programme, konselor berusaha mengubah keyakinan maladaptive dan disfungsional dari konseli yang menjadi korban bencana tsunami menjadi sehat/normal kembali. Kelima, Evaluative Progres, konselor melakukan penilaian sejauh mana kemajuan dan perubahannya yang telah dicapai. Keenam, Prepare the client for termination, pada tahap akhir ini konselor perlu memberikan penguatan, dan memberitahukan kemungkinan adanya pengulangan kejadian yang menimbulkan traumatik, sehingga mereka bisa menyelesaikan masalahnya secara mandiri (self help/self counselling).

\section{SARAN}

Konseling CBT (Cognitive Behavior Therapy) merupakan salah satu upaya bantuan yang bisa diberikan pada individu/ masyarakat yang mengalami kondisi trauma. Dalam pelaksanaannya konselor perlu mengembangkan dan memodifikasi dengan berbagai pendekatan sesuai dengan kondisi klien/konselinya. Untuk itu diharapkan ada penelitian lanjutan yang menguji efektifitas layanan konseling CBT dalam mereduksi trauma masyarakat akibat bencana tsunami.

\section{DAFTAR PUSTAKA}

Asrori, Adib. (2015). Terapi Kognitif Prilaku Untuk Mengatasi Gangguan Kesemasan Sosial. Jurnal Ilmiah Psikologi Terapan, (online), 03, (01): 91,

Froggatt, Wayne. (2009). A Brief Introduction to Cognitive-behaviour Therapy, page: 4-5 (http://www.rational.org.nz/prof-docs/IntroCBT.pdf) diakses tanggal 12 Januari 2019.

Mutmainnah. (2013). Penerapan Konseling Traumatik Untuk Mengurangi Sindrom Pasca Trauma Korban bencana Lumpur Lapindo Pada Siswa Kelas VIII A SMP Tri Bakti Tanggulangin Sidoarjo. Jurnal BK UNESA, (online), 3 (1), $309 . \quad$ (http://jurnalmahasiswa.unesa. ac.id) , diakses pada 10 Januari 2019 
Nani, Nurrohman. (2007). Pemulihan Trama: Panduan Praktis Pemulihan Trauma Akibat Bencana Alam. LPSP3. UI Jakarta. Hal.4-5.

Nirwana, Herman. (2012). Konseling Trauma Pasca Bencana. Jurnal Ta"dib (online), 15 (2): 125.

Pratama, Nanda, Aswab. (2018). Tujuh Tsunami yang Pernah Melanda Indonesia, (https://regional. kompas.com/read/2018/09/29/18474791/tujuh-tsunami-yang-pernah-melanda-indonesia). Diakses tanggal 12 Januari 2019

Priscilla Dass-Brailsford, (2007). A Practical Approach to Trauma Empowering Interventions. Georgetown University, USA, SAGE Publication, Inc USA (online). 92.
Pusat Konseling Trauma, UMM Malang. (2018). Pengertian Konseling Trauma,. (http://pkt. umm.ac.id/id/pages/artikel). diakses pada 17 Januari 2019.

Rusmana, Nandang, dkk. (2012). Mereduksi Trauma Tsunami Melalui Cognitif Behavior Therapy. Prosiding International SeminarEWorkshop, (online), 1 (1): 10-12

Yusuf, Umar, Setianto, R Luki. (2013). Efektifitas Cognitive Behavior Therapy Terhadap Penurunan Derajat Stress. Jurnal Mimbar. (online). 29 (2): 177. 